\title{
Hubungan Tingkat Aktivitas Fisik dengan Fungsi Kognitif pada Lansia di Panti Sosial Tresna Wredha Kalimantan Selatan
}

\author{
Relationship between Level of Physical Activity and Cognitive Fungtion in the Elderly at Tresna \\ Wredha Social Care in South Kalimantan
}

\author{
Dede Marizal Sesar ${ }^{1 *}$, Fakhrurrazy ${ }^{2}$, Roselina Panghiyangani ${ }^{3}$ \\ ${ }_{1}$ Program Studi Pendidikan Dokter, Fakultas Kedokteran, Universitas Lambung Mangkurat, Banjarmasin \\ ${ }^{2}$ Bagian Neurologi, Fakultas Kedokteran, Universitas Lambung Mangkurat, Banjarmasin \\ ${ }^{3}$ Bagian Biologi, Fakultas Kedokteran, Universitas Lambung Mangkurat, Banjarmasin
}

DATA OF ARTICLE:

Received: 18 Sep 2017

Reviewed: 3 Jan 2018

Revised: 27 Jun 2018

Accepted: 3 Nov 2018

*CORRESPONDENCE:

dede.sesar@gmail.com

DOI:

10.18196/mm.190125

TYPE OF ARTICLE: Research

\begin{abstract}
Abstrak: Salah satu masalah kesehatan yang sering terjadi pada golongan lanjut usia adalah gangguan fungsi kognitif. Penurunan tingkat aktivitas fisik diduga menjadi faktor menurunnya fungsi kognitif pada lansia. Tujuan penelitian ini dilakukan untuk mengetahui hubungan tingkat aktivitas fisik dengan fungsi kognitif pada lansia. Penelitian ini menggunakan metode observasional analitik, dengan pendekatan cross sectional study. Populasi penelitian adalah lansia yang tinggal di Panti Sosial Tresna Wredha Budi Sejahtera Kalimantan Selatan. Sampel penelitian sebanyak 39 responden dengan teknik purposive sampling. Kriteria inklusi adalah usia > 60 tahun, laki-laki, bersedia menjadi responden. Lansia yang mengalami gangguan neuropsikiatrik, gangguan pendengaran dan pengelihatan tidak diikutkan sebagai responden. Tingkat aktivitas fisik dinilai menggunakan kuesioner General Practicioner Physical Activity Questionaire (GPPAQ), sedangkan untuk mengetahui nilai fungsi kognitif menggunakan Mini Mental State Examination (MMSE). Analisis data menggunakan uji Fischer. Hasil penelitian menunjukkan bahwa 72\% tingkat aktivitas fisik aktif dan 28\% pasif. Sebesar 59\% fungsi kognitif buruk dan 41\% fungsi kognitif baik. Hasil uji statistik menunjukkan tidak terdapat hubungan yang bermakna $\mathrm{p}>0,05$. Disimpulkan bahwa sebagian besar lansia laki-laki memiliki tingkat aktivitas fisik tergolong aktif (72\%), namun 59\% memiliki fungsi kognitif tergolong buruk. Secara statistik terbukti bahwa tingkat aktivitas fisik tidak berhubungan dengan fungsi kognitif.
\end{abstract}

Kata kunci: Tingkat Aktivitas Fisik; Fungsi Kognitif; Lansia

Abstract: One of issues which usually occurs in elderly is cognitive function impairment. Lowering of physical activity level is assumed as the factor which influences cognitive function in elderly. This research was conducted to discover the correlation between physical activity level and cognitive function in elderly. This research was analytical observational with cross-sectional study. The Population are the elder who lived at Tresna Wredha Social Care Budi Sejahtera South Kalimantan. 39 respondents was collected by using purposive sampling. Inclusion criteria are age $>60$ years old, male, willing to be respondent. Elderly who have neuropsychiatric disorders, hearing loss and vision are not included as respondents. Physical activity level is assessed by GPPAQ (General Practitioner Physical Activity Questionnaire), cognitive function is assessed by Mini Mental State Examination (MMSE). Data was analyzed by using Fischer test. The result portrayed $72 \%$ active physical activity level and 28\% less active. 41\% normal cognitive function and 59\% cognitive function impairment. Statistical test result portrayed that there is no significantly correlation with $p$ 
value $>0,05$. It was concluded that the majority of elderly men had relatively active levels of physical activity (72\%), but $59 \%$ had classified cognitive functions as poor. Statistically it is proven that the level of physical activity is not related to cognitive function.

Keywords: Physical Activity Level; Cognitive Function; Elderly

\section{PENDAHULUAN}

Di Indonesia, jumlah lanjut usia (lansia) semakin meningkat. Pada tahun 2010, jumlah lansia diperkirakan 18,1 juta orang (7,6\% total penduduk), dan berjumlah 20,24 juta orang pada tahun 2014 (8,03\% total penduduk). Diperkirakan jumlah lansia akan berjumlah 36 juta orang pada tahun 2025. Peningkatan jumlah penduduk lansia di Indonesia tersebut kemungkinan disebabkan oleh meningkatnya Angka Harapan Hidup (AHH). Angka Harapan Hidup meningkat seiring dengan meningkatnya derajat kesehatan dan kesejahteraan penduduk Indonesia. ${ }^{1,2}$

Dalam aspek kesehatan, akan muncul problem semakin banyak keluhan akibat semakin bertambah tuanya umur lansia. Angka kesakitan pada lansia yaitu keluhan kesehatan akibat usia tua sehingga mengganggu kegiatan sehari-hari juga semakin meningkat. Masalah kesehatan pada lansia umumnya diakibatkan oleh adanya penurunan fungsi organ dan imunitas tubuh sehingga juga terjadi peningkatan faktor risiko terhadap penyakit. Adapun beberapa penyakit yang sering diderita oleh lansia antara lain adalah hipertensi, osteoporosis, penurunan fungsi penglihatan dan pendengaran, serta gangguan kognitif. ${ }^{2}$

Gangguan kognitif merupakan salah satu gangguan kesehatan yang sering dialami lansia. Kenaikan usia per 5 tahun dari usia 60 tahun akan meningkatkan 2 kali lipat risiko mengalami penurunan fungsi kognitif. Selain akibat bertambahnya usia, fungsi kognitif juga dipengaruhi oleh beberapa faktor antara lain kebiasaan merokok, mengkonsumsi alkohol, gangguan mental depresi, dukungan sosial yang kurang, gangguan fungsi fisik dan kurangnya aktivitas fisik. ${ }^{3}$ Faktor-faktor gaya hidup seperti aktivitas fisik, status sosial dan kegiatan yang bersifat menstimulasi intelektual, dapat menurunkan risiko terjadinya gangguan yang berhu-bungan dengan fungsi kognitif. ${ }^{4}$

Penelitian Muzamil et al. (2014), ${ }^{5}$ membuktikan bahwa terdapat kaitan antara aktivitas fisik dan fungsi kognitif. Dikatakan bahwa aktivitas fisik yang tinggi dan rutin serta berkelanjutan berkaitan dengan skor fungsi kognitif yang tinggi dan penurunan fungsi kognitif. Sementara itu, menurunnya in- tensitas dan durasi aktivitas fisik dapat berakibat pada meningkatnya proses penurunan fungsi kognitif.

Aktivitas fisik tinggi dan dilakukan secara rutin akan berdampak pada meningkatnya persediaan nutrisi otak dan juga mempertahankan aliran darah di otak. Aktivitas fisik juga berperan dalam memperbaiki metabolisme neurotransmiter di otak dan dapat menjaga plastisitas otak dengan cara memicu perubahan aktivitas molekuler dan seluler di otak. Selain itu aktivitas fisik juga dapat menstimulasi faktor neurotropik dan neuronal growth yang bermanfaat sebagai fungsi neuroprotektif. Kemungkinan faktor-faktor tersebut dapat menghambat penurunan fungsi kognitif., ${ }^{6,7}$

Meskipun telah banyak penelitian tentang hubungan aktivitas fisik dengan fungsi kognitif pada lansia, namun kebanyakan penelitian memiliki subyek perempuan atau setidaknya kelompok dengan prosentase perempuan lebih banyak. Penelitian ini bertujuan untuk menganalisis hubungan antara tingkat aktivitas fisik dengan fungsi kognitif pada lansia laki-laki penghuni Panti Wreda.

\section{BAHAN DAN CARA}

Penelitian ini bersifat observasional analitik menggunakan desain cross sectional. Populasi penelitian ini adalah lansia laki-laki penghuni Panti Sosial Tresna Wredha Kalimantan Selatan. Panti ini dihuni oleh lansia yang berjumlah 138 orang, terdiri dari 55 lansia laki-laki dan 83 lansia perempuan.

Teknik pengambilan sampel penelitian ini menggunakan metode purposive sampling. Adapun kriteria inklusinya antara lain adalah usia lebih dari 60 tahun, jenis kelamin laki-laki, mengerti bahasa Indonesia atau bahasa Banjar dan bersedia menjadi responden. Kriteria ekslusi dalam penelitian ini adalah terdapat gangguan neuropsikiatrik seperti demensia, skizofrenia, stroke, dan terdapat gangguan pendengaran dan penglihatan.

Penelitian ini dilakukan pada periode AgustusSeptember 2016 di Panti Sosial Tresna Wredha Kalimantan Selatan yang terdiri atas 2 lokasi. Panti 1 terletak di Jalan Jenderal A.Yani Kilometer 21,7 Landasan Ulin Utara, Banjarbaru. Panti 2 terletak di Jalan Jenderal A.Yani Kilometer 38 Sungai Paring, Martapura.

Instrumen pada penelitian ini adalah kuesioner Mini Mental State Examination (MMSE) untuk menilai fungsi kognitif dan kuesioner General Practicioner Physical Activity Questionaire (GPPAQ) untuk menilai tingkat aktivitas fisik. Data dianalisis menggunakan uji Chi-Square pada tingkat kepercayaan 95\% untuk mengetahui signifikansi hubungan antara aktivitas fisik dengan fungsi kognitif. ${ }^{8}$ 
Tabel 1. Karakteristik Subjek Penelitian dan Analisis Bivariat Masing-masing Variabel dengan Fungsi Kognitif

\begin{tabular}{|c|c|c|c|c|c|c|}
\hline \multirow[b]{2}{*}{ Variabel } & \multirow[b]{2}{*}{ Kategori } & \multicolumn{2}{|c|}{ Fungsi Kognitif } & \multirow[b]{2}{*}{ Total } & \multirow[b]{2}{*}{$P$} & \multirow[b]{2}{*}{$\mathrm{RO}$} \\
\hline & & $\begin{array}{c}\text { Normal } \\
\mathrm{N}=16(41 \%)\end{array}$ & $\begin{array}{c}\text { Tidak Normal } \\
\mathrm{N}=23(59 \%)\end{array}$ & & & \\
\hline \multirow{2}{*}{ Usia } & $\geq 75$ & $12(31 \%)$ & $17(44 \%)$ & $29(74 \%)$ & \multirow{2}{*}{1,000} & \multirow{2}{*}{1,059} \\
\hline & $61-74$ & $4(10 \%)$ & $6(15 \%)$ & $10(26 \%)$ & & \\
\hline \multirow{2}{*}{ Akivitas Fisik } & Aktif & $12(31 \%)$ & $16(41 \%)$ & $28(72 \%)$ & \multirow{2}{*}{1,000} & \multirow{2}{*}{1,312} \\
\hline & Pasif & $4(10 \%)$ & $7(18 \%)$ & $11(28 \%)$ & & \\
\hline \multirow{2}{*}{ Riwayat Hipertensi } & Ada & $7(18 \%)$ & $10(26 \%)$ & $17(44 \%)$ & \multirow{2}{*}{0,987} & \multirow{2}{*}{1,011} \\
\hline & Tidak ada & $9(23 \%)$ & $13(33 \%)$ & $22(56 \%)$ & & \\
\hline \multirow{2}{*}{ Tingkat Pendidikan } & Dasar & $14(36 \%)$ & $22(56 \%)$ & $36(92 \%)$ & \multirow{2}{*}{0,557} & \multirow{2}{*}{0,318} \\
\hline & Lanjut & $2(5 \%)$ & $1(3 \%)$ & $3(8 \%)$ & & \\
\hline
\end{tabular}

\section{HASIL}

Berdasarkan kriteria yang telah ditentukan didapatkan sampel berjumlah 39 orang. Karakteristik subjek penelitian dan analisis bivariat masing masing variabel dengan fungsi kognitif disajikan pada Tabel 1.

Sebagian besar responden memiliki tingkat aktivitas fisik yang aktif yaitu sebanyak 28 orang (72\%). Penelitian ini menunjukkan hasil yang sama dengan penelitian yang juga dilakukan di Panti Wredha oleh Nafidah (2014), ${ }^{9}$ yang menunjukkan bahwa sebagian besar lansia memiliki aktivitas yang baik, yaitu sebanyak 62 orang (52,5\%), sedangkan responden yang memiliki fungsi kognitif yang buruk terdapat sebanyak 23 orang (59\%). Hal ini juga ditemukan pada penelitian Nafidah (2014), ${ }^{9}$ yang juga dilakukan di panti sosial menunjukkan bahwa sebanyak 68 orang (57,6\%) memiliki fungsi kognitif buruk. Banyaknya responden yang memiliki aktivitas aktif disebabkan karena terdapat jadwal kegiatan rutin yang diagendakan oleh pihak panti seperti senam yang terjadwal pada hari selasa dan kamis dari jam 8-10 pagi, kegiatan ceramah setiap hari jumat pagi, serta kerja bakti yang dapat diikuti oleh penduduk panti pada hari sabtu.

Analisis Chi-squares untuk mengetahui hubungan tingkat aktivitas fisik dengan fungsi kognitif menunjukkan nilai $p>0,05$. Hal ini membuktikan bahwa tidak ada signifikansi hubungan antara tingkat aktivitas fisik dengan fungsi kognitif pada lansia laki-laki penghuni Panti Wredha.

\section{DISKUSI}

Hasil penelitian menunjukkan kesamaan dengan penelitian Miu et al. (2008), ${ }^{10}$ yang menunjukkan bahwa tidak ada signifikasi hubungan antara tingkat aktivitas fisik dengan fungsi kognitif. Pada penelitian Miu et al. (2008), ${ }^{10}$ nilai MMSE menurun seiring berjalannya waktu pada kedua kelompok baik yang melakukan aktivitas fisik maupun yang tidak melakukan aktivitas fisik. Pada penelitian tersebut terbukti bahwa aktivitas fisik memang dapat meningkatkan kemampuan fisik dalam keseharian, tetapi untuk fungsi kognitif tidak ditemukan perbedaan bermakna antara responden yang melakukan aktivitas fisik dibandingkan dengan responden yang tidak melakukan aktivitas fisik. Peningkatan kemampuan fisik dapat dihubungkan pada kesehatan fisik yang lebih baik dan fungsi gerak yang dapat menunjang kesehatan kaum lansia. ${ }^{10}$

Pada penelitian ini tidak dikumpulkan data mengenai riwayat pengalaman bekerja, interaksi sosial, serta nutrisi. Faktor-faktor tersebut dapat mempengaruhi fungsi kognitif. Oleh karena itu, kemungkinan ketiga faktor tersebut yang ikut berpengaruh pada fungsi kognitif pada penelitian ini.

Chung et al. (2014), ${ }^{11}$ menyebutkan bahwa pengalaman bekerja berhubungan dengan kemampuan fungsi kognitif. Semakin banyak pengalaman pekerjaan yang dimiliki, maka semakin baik fungsi kognitif. Jenis pekerjaan juga berperan pada fungsi kognitif. Semakin kompleks pekerjaan yang pernah dimiliki maka fungsi kognitif juga semakin baik. Hal ini disebabkan pekerjaan dapat melatih otak secara terus-menerus sehingga dapat mencegah penurunan fungsi kognitif.

Penelitian Wreksoatmodjo (2014) ${ }^{12}$ membuktikan bahwa interaksi sosial dapat mempengaruhi fungsi kognitif. Lansia yang mendapatkan dukungan emosional yang memadai akan memiliki fungsi kognitif yang lebih baik. Dukungan emosional dalam hal ini berperan pada fungsi kognitif sosial yang melibatkan sistem limbik.

Faktor nutrisi juga dapat mempengaruhi fungsi kognitif. Walaupun konsumsi harian ditanggung dan diatur oleh pengelola Panti, tetapi tidak diketahui makanan tambahan yang dikonsumsi lansia di luar menu yang telah disediakan. Penelitian Rahmawati et al. (2012), ${ }^{13}$ membuktikan bahwa nutrisi mikro seperti suplemen vitamin B6, C, dan E dapat mem- 
pengaruhi fungsi kognitif. Mekanisme kerja dari suplemen tersebut adalah dengan cara menurunkan kadar homosistein di darah yang merupakan faktor risiko aterosklerosis, berperan langsung pada neuron di saraf pusat, serta menangkal radikal bebas.

Ada perbedaan hasil penelitian ini dengan penelitian Muzamil et al. (2014), ${ }^{5}$ yang menunjukkan adanya signifikansi hubungan antara tingkat aktivitas fisik dengan fungsi kognitif. Mekanisme yang terjadi pada aktivitas fisik terhadap fungsi kognitif yaitu adanya angiogenesis pada otak, menjaga plastisitas otak, menjamin perfusi jaringan otak serta pelepasan growth factor seperti IGF-1 dan BDNF. Pada penelitian Muzamil et al. (2014), ${ }^{5}$ data mengenai riwayat pekerjaan dan tingkat pendidikan menunjukkan bahwa responden yang masih bekerja sebanyak $31,4 \%$ dan yang sudah tidak bekerja sebanyak 68,6\%. Aspek pendidikan responden menunjukkan bahwa persentase tertinggi responden adalah tamat SMA atau sederajat (51\%), sedangkan persentase terendah adalah tamat akademi atau perguruan tinggi (15,7\%). Sampel penelitian Muzamil et al. (2014), ${ }^{5}$ tersebut adalah laki-laki dan perempuan, sedangkan penelitian ini semua resonden adalah laki-laki. Perbedaan karakteristik responden inilah yang kemungkinan menyebabkan adanya perbedaan dengan hasil penelitian Muzamil et al. (2014). ${ }^{5}$

Pada penelitian ini, analisis riwayat hipertensi dengan fungsi kognitif juga tidak memiliki hubungan yang bermakna ( $p>0,05)$. Hasil yang sama juga terjadi pada penelitian Amalia (2014), ${ }^{14}$ yang menunjukkan bahwa tidak ada signifikansi hubungan antara hipertensi dengan fungsi kognitif. Hal ini mungkin terjadi karena Panti Wredha sebagai lokasi penelitian memiliki poliklinik yang rutin memberikan obat anti hipertensi sehingga kemungkinan tekanan darah penderita hipertensi selalu terkontrol.

Variabel usia juga menunjukkan tidak ada signifikansi hubungan dengan fungsi kognitif. Hal yang sama juga ditemukan pada penelitian Rohmah et al. (2014), ${ }^{15}$ yang menyebutkan bahwa usia tidak berhubungan dengan fungsi kognitif. Hal ini disebabkan karena pengelompokan usia pada penelitian Rohmah et al. (2014), ${ }^{15}$ dibagi menjadi kelompok usia 6064, 65-70, dan 71-75. Kelompok tersebut masih termasuk dalam golongan lansia dan bukan mengelompokkan pada semua golongan usia. Salthouse (2009), ${ }^{16}$ menyebutkan bahwa penurunan fungsi kognitif akan terjadi seiring dengan menuanya usia. Penurunan biasanya dimulai pada umur 60-70an. Hal ini disebabkan pada peningkatan usia, beberapa fungsi tubuh mengalami penurunan terutama pada bagian otak dan vaskuler. Beberapa fungsi antara lain kecepatan belajar, kecepatan memproses informasi baru dan kecepatan bereaksi terhadap rangsangan baik rangsangan sederhana maupun kom- pleks, akan mengalami penurunan secara terus menerus. Penurunan hal-hal tersebut berbeda antar individu. ${ }^{17}$

Tingkat pendidikan juga tidak berhubungan secara signifikan dengan fungsi kognitif. Hasil ini sama dengan penelitian Van Dijk et al. (2008), ${ }^{18}$ yang menunjukkan bahwa tidak ada signifikansi hubungan antara tingkat pendidikan dengan fungsi kognitif. Pada penelitian Van Dijk et al. (2008), ${ }^{18}$ tersebut disebutkan bahwa tidak adanya hubungan tingkat pendidikan dengan fungsi kognitif mungkin karena sedikitnya responden yang memiliki tingkat pendidikan yang tinggi.

Hasil penelitian ini menunjukkan bahwa semua variabel yang diteliti yaitu usia, riwayat hipertensi, aktivitas fisik dan tingkat pendidikan tidak menunjukkan adanya hubungan yang bermakna dengan fungsi kognitif. Selain alasan yang telah dikemukakan, kemungkinan ada pengaruh dari keterbatasan penelitian ini, yaitu desain penelitian cross-sectional yang hanya meneliti pada satu waktu sehingga tidak dapat melihat perubahan yang sesungguhnya. ${ }^{19}$ Perlu dipertimbangkan desain penelitian cohort prospective agar dapat melihat perubahan yang sesungguhnya pada responden dengan membagi responden menjadi dua kelompok yaitu kelompok yang mendapatkan perlakuan dan kelompok yang menjadi kontrol. Selain itu, diharapkan juga mengontrol variabel pengganggu yang dapat menjadi faktor yang berpengaruh terhadap fungsi kognitif seperti riwayat pekerjaan, interaksi sosial serta nutrisi.

\section{SIMPULAN}

Hasil penelitian dapat disimpulkan bahwa sebagian besar lanjut usia laki-laki yang tinggal di Panti Sosial Tresna Wredha Budi Sejahtera Kalimantan Selatan memiliki tingkat aktivitas fisik tergolong aktif (72\%) namun 59\% diantaranya memiliki fungsi kognitif tergolong buruk. Secara statistik terbukti bahwa tingkat aktivitas fisik tidak berhubungan dengan fungsi kognitif.

\section{DAFTAR PUSTAKA}

1. Kementerian Kesehatan RI. Infodatin Pusat Data dan Informasi Kesehatan: Situasi dan Analisis Lanjut Usia. Jakarta: Kementrian Kesehatan RI. 2014.

2. Badan Pusat Statistik. Statistik Penduduk Lanjut Usia 2014. Jakarta: Badan Pusat Statistik. 2015.

3. Azizah LM. Keperawatan Lanjut Usia. Yogyakarta: Graha Ilmu. 2011.

4. Foster PP, Rosenblatt KP, Kuljis RO. Exerciseinduced Cognitiveplasticity, Implications for Mild Cognitive Impairment and Alzheimer's Disease. Frontiers In Neurology Dementia, 2011; 2 (28): 1-10. 
5. Muzamil MS, Afriwardi, Martini RD. Hubungan antara Tingkat Aktivitas Fisik dengan Fungsi Kognitif pada Usila di Kelurahan Jati Kecamatan Padang Timur. Padang. Jurnal Kesehatan Andalas, 2014; 3 (2): 202-205.

6. Kirk-Sanchez NJ, McGough EL. Physical Exercise and Cognitive Performance in the Elderly: Current Perspectives. Clin Interv Aging, 2014; 9 (1): 51-62.

7. Hernandez SS, Coelho FGM, Gobbi S, Stella F. Effects of Physical Activity on Cognitive Functions, Balance and Risk of Falls in Elderly Patients with Alzheimer's Dementia. Rev Bras Fisioter Sao Carlos, 2010; 14 (1): 68-74.

8. Dahlan MS. Statistik untuk Kedokteran dan Kesehatan Deskriptif, Bivariat dan Multivariat, Dilengkapi Aplikasi Menggunakan SPSS. Edisi 6. Jakarta: Epidemiologi Indonesia. 2014.

9. Nafidah N. Hubungan antara Aktivitas dengan Tingkat Kognitif Lanjut Usia di Panti Sosial Tresna Wredha Budi Mulia 4 Margaguna Jakarta Selatan. Jakarta: FK UIN Syarif Hidayatullah. 2014.

10. Miu DKY, Szeto SL, Mak YF. A Randomised Controlled Trial on the Effect of Exercise on Physical, Cognitive and Affective Function in Dementia Subjects. Asian J Gerontol Geriatri, 2008; 3 (1): 8-16.

11. Chung J, Park J, Cho M, Park Y, Kim D, Yang Y. A Study on the Relationships between Age, Work Experience, Cognition and Work Ability in Older Employees Working in Heavy Industry. J Phys Ther Sci, 2015; 27 (1): 155-157.
12. Wreksoatmodjo BR. Beberapa Kondisi Fisik dan Penyakit yang Merupakan Faktor Risiko Gangguan Fungsi Kognitif. CDK. 2014, 41 (1): 25-32.

13. Rahmawati A, Pramantara IDP, Martalena BP. Asupan Zat Gizi Mikro dengan Fungsi Kognitif pada Lanjut Usia. Jurnal Gizi Klinik Indonesia, 2012: 8 (4): 195-201.

14. Amalia DR. Hubungan Hipertensi dengan Fungsi Kognitif. Aceh: Fakultas Kedokteran Syiah Kuala. 2014.

15. Rohmah ASN. Hubungan antara Gangguan Gerak dan Fungsi Kognitif pada Wanita Lanjut Usia di Panti Wredha Surakarta. Surakarta: Fakultas Kedokteran Universitas Muhammadiyah Surakarta. 2009.

16. Salthouse T. Interrelations of Aging Knowledge and Cognitive Performance. USA: University of Virginia. 2002.

17. Lumbantobing S. Kecerdasan pada Usia Lanjut dan Demensia. Edisi keempat, Jakarta: Balai penerbit FKUI. 2006.

18. Van dijk KRA, Van Gerven PWM, Van Boxtel MPJ, Van der Elst W, Jolles J. No Protective Effects of Education During Normal Cognitive Aging: Results From the 6-Year Follow-Up of the Maastricht Aging Study. American Psychological Association, 2008; 23 (1): 119-130.

19. Etnier JL, Nowell PM, Landers DM, Sibley BA. A Meta-Regression to Examine the Relationship between Aerobic Fitness and Cognitive Performance. Brain Res Rev, 2006; 50 (1): 119130. 